\title{
THE CALCULATION OF THE BARYCENTER AS A CRITERION FOR DETERMINING THE LOCATION OF THE AMBULANCE OPERATIONAL BASE
}

\author{
Josiano César de Sousa ${ }^{1 *}$, Murilo Barros Alves ${ }^{2}$ and \\ José de Figueiredo Belém ${ }^{3}$
}

Received January 01, 2019 / Accepted October 16, 2020

\begin{abstract}
This article presents an analysis to determine the location of the operational base of the ambulance dispatch service by applying the barycenter calculation, using as an object of study the Emergency Medical Assistance Service - SAMU. The research was performed by the quantitative modeling method, through an applied research, so that the results could be used to solve the following problem: How to determine the location of an operational base according to service history? Thus, the objective of this paper is to evaluate the applicability of Operational Research, through the barycenter calculation method as a tool to determine the best location of the operational base. To this end, we analyzed the history of 19,711 calls made from 2010 to 2016, using the software "R-Studio" for a quantitative treatment, which resulted in the proposition of a viable and reliable solution to the problem, validating the method proposed.
\end{abstract}

Keywords: calculation of barycenter, location, operational base.

\section{INTRODUCTION}

The answering service of an operational base of ambulance service is a logistics network that has particularities that need to be studied to find better alternatives to their allocation and structuring process aiming to meet the demands for service more efficiently.

When analyzing a public emergency care logistics system, one of the main objectives pursued is to raise the level of services and determine the service base. In this case, the location of the base greatly contributes to improving the response time to meet demands, improving service coverage rates, because when the service is efficiently designed and operated, it can save lives. (Takeda, Eidmer \& Morabito, 2003).

\footnotetext{
*Corresponding author

1 Programa de Pós-graduação em Engenharia de Produção e Sistemas, Universidade do Vale do Rio dos Sinos, Brasil E-mail: josianocesar@hotmail.com - http://orcid.org/0000-0002-9888-3440

2 Programa de Pós-graduação em Engenharia de Produção e Sistemas, Universidade do Vale do Rio dos Sinos, Brasil E-mail: muriloimp@yahoo.com.br - http://orcid.org/0000-0002-6999-8345

3 Programa de Pós-graduação em Engenharia de Produção e Sistemas, Universidade do Vale do Rio dos Sinos, Brasil E-mail: jose.belem@ig.com.br - http://orcid.org/0000-0003-4100-7172
} 
Among the methods used to carry out the analysis aiming at determining the location of the operational base, some can be quantitative, requiring more efforts and often the use of computational equipment (Lorena, 2003). The use of objective quantitative methods can contribute to avoid errors of interpretation or affinities between decision makers (Fitzsimmons \& Fitzsimmons, 2004).

In view of this, this article sought to use the method of calculating the barycenter, using the software R-Studio (Jatain \& Ranjan, 2017) to identify the best possible location for the operational base of the Mobile Emergency Care Service, based on service history of the last seven years in a medium-sized Brazilian city.

This work was based on a documentary research, using the method of quantitative modeling through applied research so that the results could be used to solve the following problem: how to determine the location of an ambulance service operational base according to the history service? Therefore, the article will not be dedicated to analyzing the service time, nor the costs of installation and maintenance of the operational bases, stopping to discuss the location of the operational base.

Regarding the approach, the research used quantitative data, which served as a basis for the application of the model. (Silva and Menezes, 2001) and used a cross-section with a temporal analysis of the period between the years 2010 and 2016, involving the collection of data in a continuous moment in time (Pollit et al., 2004).

The results achieved confirm the importance of analyzing the history of the consultations performed to assist in the process of analysis and decision making regarding the location of the operational base for dispatching ambulances (Iannone \& Morabito, 2006) through the calculation of the barycenter.

\section{LITERATURE REVIEW}

\subsection{Mobile emergency care service SAMU}

The history of pre-hospital care in Brazil dates back to 1949, when the government of President Getúlio Vargas created SAMDU - Home and Emergency Medical Assistance Service (Almoyna \& Nitschke, 1999) apud Aquino 2007.

In 1988, the city of São Paulo became the first Brazilian capital to develop a mobilization in prehospital care, through an agreement signed between the Brazilian government and the French government, implementing a system that was then called Rescue". Initially, the system was linked to the fire department, where a doctor from the State Health Department was in the barracks, to assist victims of accidents on public roads through requests that were made by telephone 193 (Lopes \& Fernandes. 1999, apud Aquino, 2007). And, in 1995, a system called Network 192 was created, which later became Brazilian Network for Cooperation in Emergencies - RBCE, formed by managers of the Unified Health System (SUS) in Brazil (Aquino, 2007). 
In 2003, the Brazilian Ministry of Health, through ordinance 1.863/03, created the National Emergency Care Policy and, through ordinance 1.864/2003, promoted the implementation of the Mobile Emergency Care Service (SAMU - 192). The first operational base of SAMU-192 was implemented in the city of Campinas / SP, in 2005 and attended to 64,131 occurrences that year (DATASUS, 2017).

SAMU operates 24 hours a day, every day of the year. Its main objective is to provide medical assistance in an agile manner to people who need to be referred to urgent or emergency care in hospitals or Emergency Care Units (UPA), in order to avoid trauma, sequelae or the death of the patient (Brasil, 2017).

In 2017, SAMU served $76.9 \%$ of the Brazilian population, with operational bases located in 3,052 Brazilian municipalities, operating with 3108 ambulances, of which 583 operate with advanced support. The system also counts on the assistance of 226 motorbikes to reach the accident site more quickly, 13 ambulances installed on boats and 7 air service teams (Brasil, 2017), which integrate the system and seek to provide assistance to victims, reducing the time of rescue and service.

\subsection{Impacts of minimizing rescue time}

Despite a wide range of calls made annually by the SAMU system, the majority of calls, currently, are to assist accident victims. Traffic accidents are among the top 10 causes of mortality and morbidity worldwide. Even considering the increase in investments in infrastructure improvements and safety on the highways, the increase in the rigidity of safety standards and the technological evolution observed in vehicles, there is a growing trend in the number of accidents worldwide (Parkinson et al, 2014; Hsu et al, 2015, apud Ferrari \& Nassi, 2015).

The moment an accident occurs, the longer there is a delay in assisting the victim, the greater the dangers of aggravating the situation, and, therefore, it is extremely important to reduce the arrival of the rescue team at the accident site (Barrachina et al, 2014). The reduction in the time of arrival of the medical assistance, which in the Brazilian average, takes 15 minutes (Fogue et al. 2013), can be the difference between the assistance and the death of the victim, being, therefore, of extreme importance that the same can occur in the shortest possible time.

The length of care is also of fundamental importance for victims of natural causes. Bertelli et al. (1999) affirm that, when medical assistance occurs in up to 8 minutes, the greater the chances of survival of victims who suffer cardiac arrest, for example. One of the great challenges of SAMU is to decrease the time between the announcement of the accident at the operational base and the arrival of the team at the service location, therefore, the correct location of the operational base is a determining factor in order to promote agility and to be able to perform a more agile and efficient travel. 


\subsection{Ambulance service operational base location}

Due to the fact that SAMU is a public service, the location of its operational bases is often chosen without due technical criteria that could contribute to making the movement of ambulances and teams more agile and efficient, shortening the service time. Properly locating the facilities is a very important decision problem (Ballou 2006), requires the adoption of good location criteria and represents one of the most important strategic issues faced by organizations, both public and private. (Farahani et al., 2012).

Ferrari \& Nassi (2015), affirm that, in the view of Andrade (2012), defining the location of an operational base for the dispatch of ambulances, must consider a certain amount of potential points of demand for care and other potential ideal points for the location of the dispatch base, which can be arranged in a graph. The displacement point between the two points is represented by each arc of that graph. Fuller (1997) points out that the problems related to location aim to promote the best possible choice for a set of points of facilities that can meet a certain set of demands. To this end, this facility point must meet this demand point as closely or as quickly as possible.

Arakaki and Lorena (2006) classify the classes of location problems into two types: class of coverage problems and the class of median location problems. The authors emphasize that in all of them the focus is on making decisions about where to locate the bases (facility centers) and must also consider the location of the customer to be served and considers a given criterion to be optimized.

A relevant fact is that, in the public network, the determination of the location of the ambulance service's operational base is often carried out without the use of a specific scientific method, which sometimes compromises the effectiveness and efficiency of the location, negatively impacting the time to meet demands. Such an impact can be minimized when a proven method is used to assist in the process of determining the location of the operational base, leaving the largest possible area covered. For an area to be considered covered, it is necessary that any of the points in this area be within the radius of operation of at least one facility that exists in this area. (Galvão et al., 1999).

\subsection{Methods for determining the operational basis}

The literature on the topic presents several types of methods and approaches, which can be used to assist decision makers in the process of determining the location of an operational base for an ambulance service, among which we can mention the heuristic methods proposed by Teitz and Bart (1968), the PLMC approach by Church \& Revelle (1974), planning an ambulance network, addressed by Hamon et al., (1979), the considerations on the location of multiple types of vehicles and bases proposed by Schilling et al. (1979), Simulated Annealing (Chiyoshi and Galvão, 2000), the Hypercube model for analysis of non-homogeneous servers presented by Cryochi, Galvão and Morabito (2001), the resolution of optimal dispatch problems, defended by Sousa, Baptista and Costa (2008), the applicability of multi-objective mathematical programming in the 
planning of long-term expansion, presented by Albuquerque, Almeida and Cavalcante (2009) the ideal location of two types of bases, fixed and transport, mentioned by Gu, Wang and Geng (2009), among others.

Ferrari \& Nassi (2015) highlight that among deterministic methods, authors who contributed significantly with their approaches can be cited, namely: Schilling et al., (1979), Hogan \& Revelle (1986), Daskin \& Stern (1981), Yin \& Mu (2012), Haghani (1996), Alsalloum \& Rand (2006), Ball \& Lin, (1993); Marianov \& Revelle, 1996). As for the Stochastic or Probabilistic methods, according to the authors, it is possible to highlight the contributions of: Daskin (1983), Larson \& Odoni (1981), Revelle \& Hogan (1989), Marianov \& Revelle (1996), Figueiredo et al., ( 2005), Takeda et al. (2004), Iannoni et al. (2009). As for dynamic methods, the following stand out: Gendreau et al., (2001), Rajagopalan et al., (2008), Schmid \& Doerner (2010), Schmid (2012).

Despite the diversity of methods presented in the literature, a gap was noticed regarding the use of methods that are still little explored, among which the method of calculating the barycenter stands out, which will be explored in this article.

\subsection{Method of calculating the barycenter}

The oldest studies on the calculation of the barycenter are attributed to Archimedes. Other Greek mathematicians like Heron, Papus, Eutócius and Simplício also developed works on center of gravity from the writings, some lost, of Archimedes (Clareto et al., 2013).

Quantitative methods are widely explored to solve localization problems. Naruo (2003), for example, used mathematical models and computer programs to perform calculations to determine the best option for landfill locations. Galvão et al. (1999) used the application of mathematical models to define the best location for public facilities in the area of health services. And the application of the barycenter method was used by Sellitto et al. (2009) to determine the best location for a distribution center (DC).

Many methods of locating space involve the assessment of some functional linear factors. For Mazuelas (2010), location systems that use the barycenter as a method of statistical estimates are highly reliable. Area location estimation has the value of a function at some point or its integral over an interval. One approach to the problem of estimating a space (L) so functional for a function $\mathrm{f}$ of a complex variable $\mathrm{z}$, is to choose the abscissa $z_{j}, j=0(1) n$ with corresponding values $f\left(z_{j}\right)$ of $\mathrm{f}$ then replacing $\mathrm{f}$ an interpolant between the $z_{j}$ for which the function can be evaluated exactly and, finally, last evaluation as an estimate of the value of the optimal space for $\mathrm{f}$.

We will consider the functions defined on a disk centered on the source; after scaling, we take its radius to be 1 . More precisely, the function will be in the Hilbert space $H^{2}$ of functions of a complex variable $\mathrm{z}$ that are analytical within the disk and square unit integrable in the Lebesgue direction around the unit circle $\mathrm{F}$, with the scalar product equal to: 


$$
(f, g):=\frac{1}{2 \pi} \int_{\Gamma} f(z) \overline{g(z)} d z
$$

Our goal is to estimate the value of the space (L) of $\mathrm{f}$, within the Hilbert space in a limited linear area, that is:

$$
L f \approx \sum_{f=0}^{n} a_{j} f_{j}
$$

Being $a_{j}$ coefficients obtained from the occurrence information of the studied phenomenon, thus approaching the $f_{i}$ function of the best approximation of the value $(\mathrm{L})$ of the space sought. The estimated error for the function will be given by:

$$
E: f \rightarrow E f:=L f-\sum_{f=0}^{n} a_{j} f_{j}
$$

This method calculates the rational interpolants of the barycenter, their representative bariatric weights simply consisting of multiplying each interpolated value by a certain number $a_{j}$ and determining their obtained weights.

With the Barycenter method we seek a spatial point pattern, that is, a set of data that provides the observed spatial locations of things or events. Examples include the location of trees in a forest, gold deposits mapped in a geological survey, stars in a cluster, road accidents, earthquake epicenters, phone calls or cases of a rare disease (Lefebvre, 2004).

The barycenter method is a quantitative technique, which associates points on a Cartesian plane with possible geographical locations to find a point on the plane where the sum between the distances is as small as possible. (Sellitto et al 2015). This method is also presented in the literature by other names: exact center of gravity, p-gravity, median method or centroid method (Ballou, 2005).

According to Thai \& Grewal (2005), apud Matte Jr. et al (2017), within the scope of physics, the Center of Gravity is defined as an imaginary point in which all the weights of the object can be considered and concentrated through that point:

The barycenter method, when applied to locality determination problems, can select any of the points as a possible solution to the problem and, therefore, an unviable point can be pointed out as a solution, in this case, the method must undergo adaptations, passing to be called methods of the moments (Aquilano et al., 2000).

For each possible location, the product must be calculated between individual transport time and the distance to service. The result of this procedure is called the moment. Once this is done, the sum of all the moments in each location must be totaled and, in this way, obtain the general moment. The location with the lowest overall moment should be chosen as the location for the base location. (Aquilano et al., 2000). 


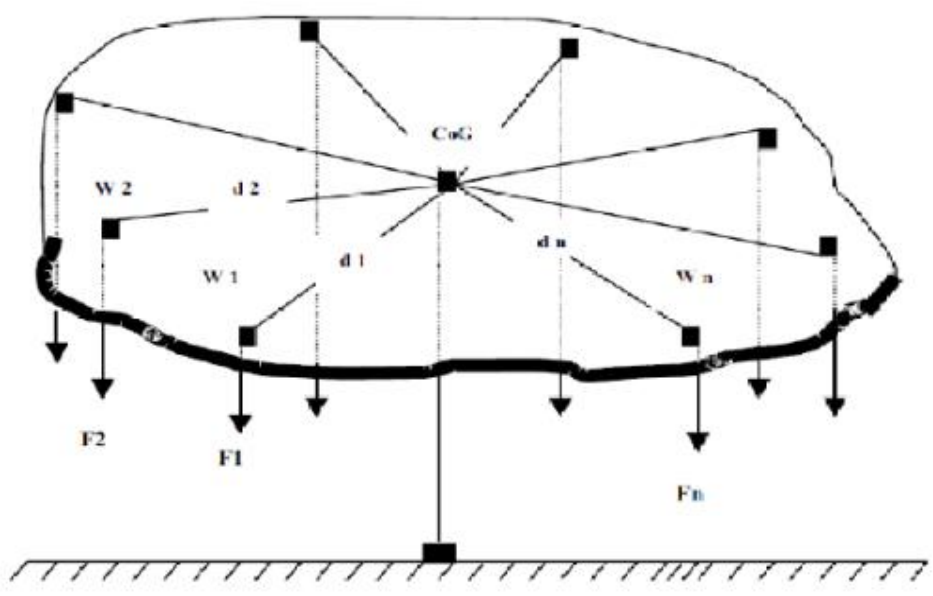

Figure 1 - Center of gravity model.

Thai \& Grewal (2005), apud Matte Jr. et al (2017).

\section{FIELD RESEARCH}

In order to carry out this article, a field research was carried out, which was based on the SAMU's service history in the city of Imperatriz-MA, over a period of seven years, between the years 2010 to 2016. The city of Imperatriz is the second most populous city in the state of Maranhão, with a population of 254,696 inhabitants (IBGE 2017), being located in the southwest region of the state.

According to DENATRAN (2017), the city has a total fleet of 131,875 vehicles, of which 73,221 are motorcycles and motorcycles, with a considerable index of potential involvement in traffic accidents, which requires an efficient performance in SAMU rescue system.

In the city, the SAMU's operating structure is composed of three operational bases, 07 ambulances of basic unit-USB, 02 ambulances of advanced units-USA and 01 motolance (motorcycle ambulance). Each of these vehicles has a service team composed of 4 people for the USAs, 02 people for the USBs and 01 person for the motolance. These teams carry out, in the period analyzed, an average of 2834 visits per year, and the people served were referred to the municipal hospital, located in the city center.

\section{METHODOLOGY}

The purpose of this article is to present a proposal for the location of an operational base for a SAMU ambulance dispatch base, using the calculation of the barycenter. The research was carried out using the quantitative modeling method through applied research so that the results could be used to solve the following problem: how to determine the location of a SAMU operational base according to the service history? 


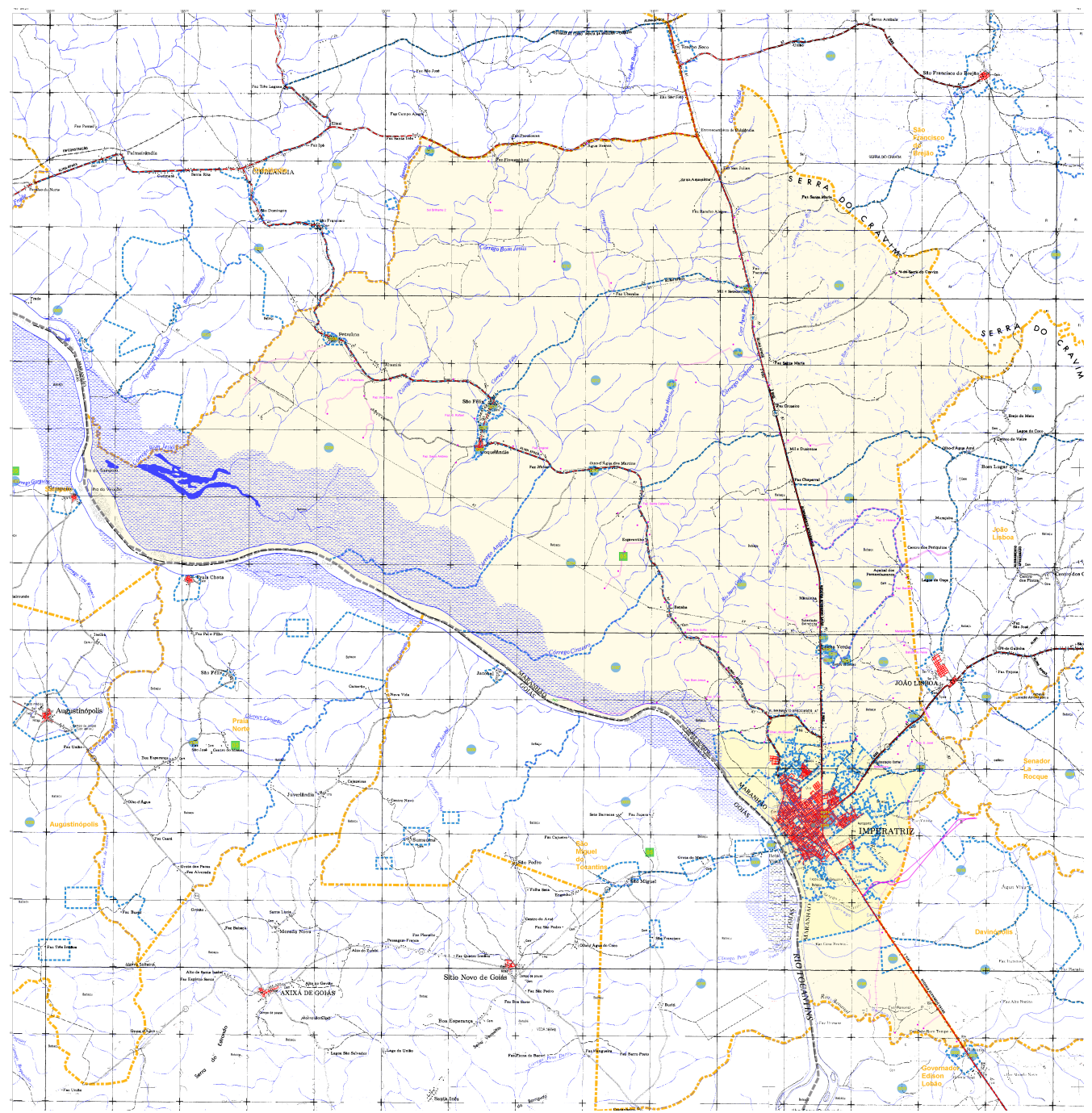

Figure 2 - Imperatriz City Map.

Source: IBGE (2017).

Regarding the approach, the research used quantitative data, which served as a basis for the application of the model (Silva \& Menezes, 2001). As for the temporal design of the research, a cross-section was used with longitudinal analysis of the period between the years 2010 and 2016, involving the collection of data in a continuous moment in time (Pollit et al., 2004).

The original database was provided by the SAMU operational base in the city of Imperatriz-MA, and refers to the history of 19,771 calls made in the period from 2010 to 2016, grouped through a monthly distribution for each of the 12 months of the 07 years surveyed, generating a total set 
Table 1 - Total fleet of vehicles in the city of Imperatriz.

\begin{tabular}{lrrr}
\hline Variable & Imperatriz & Maranhão & Brasil \\
\hline Automobiles & 40.820 & 398.265 & 51.296 .981 \\
Trucks & 4.016 & 38.994 & 2.684 .227 \\
Tractor Trucks & 451 & 4.140 & 606.679 \\
Pickup Trucks & 10.069 & 106.306 & 6.880 .333 \\
Pickup & 1.928 & 21.868 & .053 .759 \\
Micro bus & 268 & 4.652 & 383.325 \\
Motorcycles & 52.900 & 781.186 & 20.942 .633 \\
Scooters & 20.321 & 142.653 & 3.990 .558 \\
Bus & 450 & 8.472 & 601.522 \\
Tractors & 1 & 65 & 30.896 \\
Utilities & 651 & 8.469 & 707.152 \\
\hline \multicolumn{3}{c}{}
\end{tabular}

of 84 months and were distributed over 120 locations of demand for care (neighborhoods of the city), generating a set of 10,080 data.

As the calculations for determining the barycenter often go beyond the human capacity to perform them, in this article we use open source software ( $\mathrm{R}$ - Studio) easily accessible online with various packages distributed by the Comprehensive R Archive Network cran.r-project.org, making it possible to estimate various mathematical models through the analysis of databases.

The $\mathrm{R}$ software is a language and environment for computing and statistical graphics. It is a GNU project that is similar to the $\mathrm{S}$ language and environment, developed at Bell Laboratories. $\mathrm{R}$ was created by Ross Ihaka and Robert Gentleman, from the University of Auckland, New Zealand, and is currently developed by R Development.

Over the past decade, academic and industry work has used R programming, which has made it one of the most important tools for computational statistics. Worldwide, millions of statisticians and data scientists use $\mathrm{R}$ to solve their most challenging problems in the field ranging from computational biology to quantitative marketing (Jatain \& Ranjan, 2017). R has become the most popular language for data and an essential tool for finance and analytics driven companies like Google, Facebook and LinkedIn.

The tabulated data for the calculation of the barycenter needed to generate the analyzes in this article will be presented below and were performed using the following script:

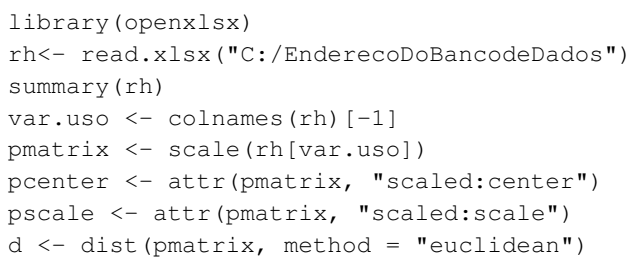




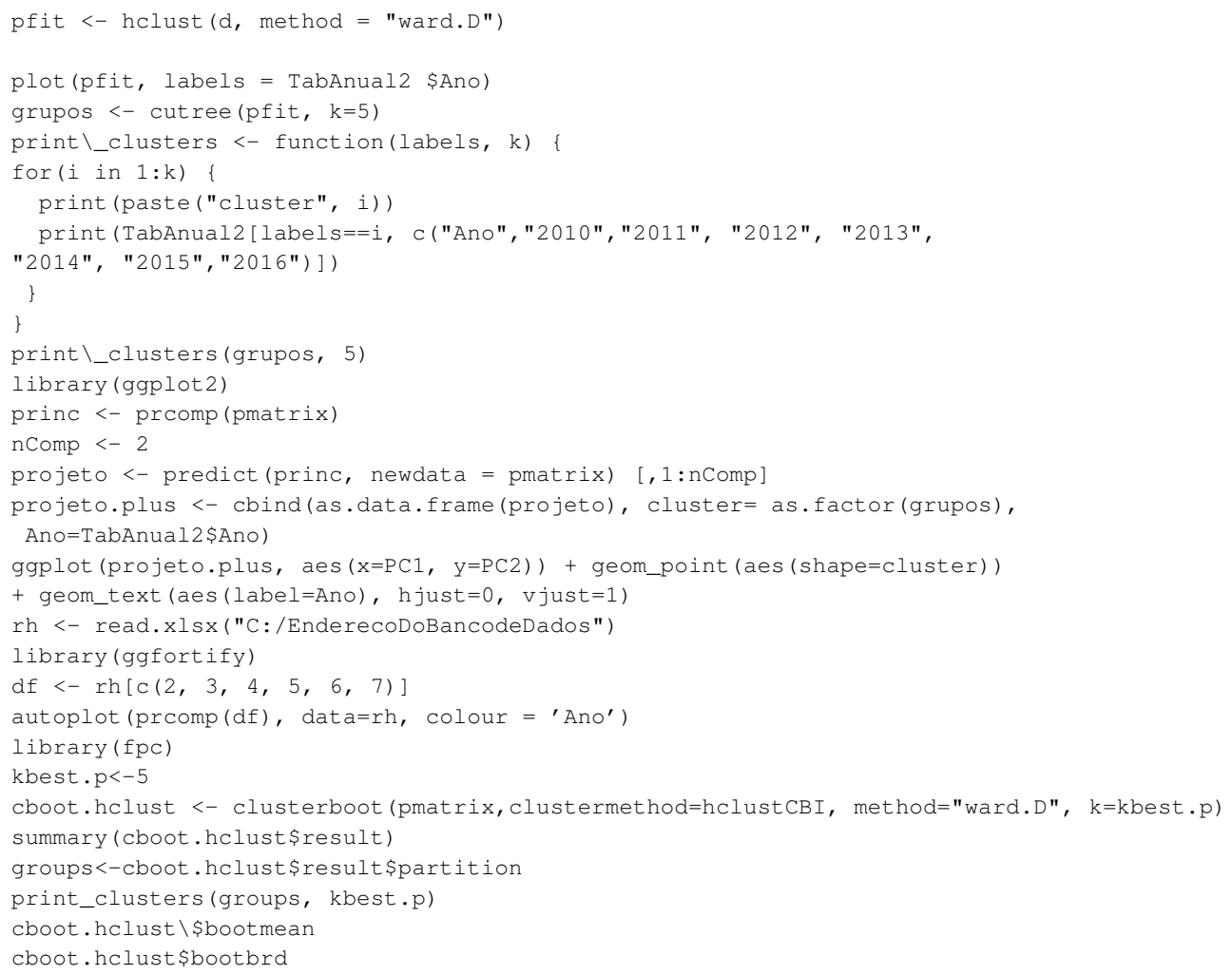

\section{RESULTS AND DISCUSSIONS}

The data collected during the survey reveal that 19,711 visits were made during the analyzed period, distributed among 120 possible points of service (neighborhoods in the city). The data referring to the quantitative distribution of the number of demands in number of calls per year are shown in Table 2.

Table 2 - Service demand in number of calls per year.

\begin{tabular}{lccccccc}
\hline \multirow{2}{*}{ Bairro } & \multicolumn{7}{c}{ Ano } \\
\cline { 2 - 9 } & 2010 & 2011 & 2012 & 2013 & 2014 & 2015 & 2016 \\
\hline MileSetessentos & 0 & 1 & 5 & 11 & 8 & 8 & 10 \\
\hline CincoIrmaos & 1 & 5 & 2 & 3 & 3 & 12 & 7 \\
\hline AguaBoa & 0 & 0 & 1 & 1 & 5 & 0 & 0 \\
\hline AltoBonito & 4 & 2 & 2 & 0 & 8 & 2 & 1 \\
\hline AltodaBoaVista & 0 & 0 & 0 & 0 & 0 & 0 & 0 \\
\hline AsaNorte & 4 & 3 & 1 & 1 & 5 & 0 & 0 \\
\hline PedroNSantana & 79 & 121 & 151 & 91 & 82 & 73 & 78 \\
\hline AyrtonSena & 7 & 6 & 10 & 6 & 1 & 2 & 2 \\
\hline Bacaba & 5 & 1 & 1 & 1 & 0 & 0 & 0 \\
\hline & & & & & Continued on next page
\end{tabular}


Table 2 - Continued from previous page

\begin{tabular}{|c|c|c|c|c|c|c|c|}
\hline \multirow{2}{*}{ Bairro } & \multicolumn{7}{|c|}{ Ano } \\
\hline & 2010 & 2011 & 2012 & 2013 & 2014 & 2015 & 2016 \\
\hline Bacuri & 205 & 343 & 318 & 239 & 169 & 194 & 201 \\
\hline Uniao & 3 & 1 & 5 & 0 & 8 & 2 & 6 \\
\hline PonteDom Afonso & 5 & 0 & 1 & 6 & 7 & 5 & 6 \\
\hline BarraGrande & 0 & 0 & 2 & 2 & 7 & 0 & 4 \\
\hline Bebedouro & 0 & 0 & 1 & 0 & 5 & 0 & 0 \\
\hline BeiraRio & 24 & 56 & 54 & 36 & 19 & 18 & 14 \\
\hline BocaDaMAta & 32 & 30 & 33 & 27 & 18 & 18 & 29 \\
\hline BomJesus & 6 & 15 & 12 & 6 & 16 & 13 & 25 \\
\hline BomSucesso & 44 & 75 & 55 & 28 & 52 & 27 & 23 \\
\hline BR010Urbano & 206 & 278 & 320 & 362 & 289 & 223 & 210 \\
\hline BR010Rural & 61 & 165 & 109 & 59 & 39 & 18 & 6 \\
\hline Cacauzinho & 2 & 8 & 6 & 6 & 3 & 3 & 3 \\
\hline Caema & 6 & 5 & 4 & 3 & 2 & 0 & 1 \\
\hline Camacari & 8 & 6 & 9 & 8 & 7 & 6 & 3 \\
\hline Centro & 509 & 775 & 650 & 493 & 510 & 414 & 475 \\
\hline CentroNovo & 8 & 6 & 4 & 6 & 5 & 5 & 6 \\
\hline CocoGrande & 13 & 18 & 21 & 18 & 26 & 40 & 24 \\
\hline CristoRei & 2 & 1 & 2 & 1 & 2 & 1 & 1 \\
\hline CjBrasilNovo & 1 & 1 & 6 & 1 & 6 & 4 & 5 \\
\hline CjCartier & 2 & 0 & 0 & 0 & 0 & 0 & 0 \\
\hline CjPlanalto & 3 & 2 & 1 & 1 & 2 & 3 & 2 \\
\hline Cjvitoria & 23 & 23 & 23 & 22 & 25 & 18 & 17 \\
\hline Curtume & 2 & 0 & 0 & 0 & 0 & 0 & 0 \\
\hline Davinopolis & 0 & 0 & 0 & 0 & 4 & 7 & 14 \\
\hline EstradadoArroz & 0 & 0 & 10 & 16 & 25 & 29 & 44 \\
\hline Habitar Brasil & 8 & 2 & 0 & 0 & 7 & 1 & 2 \\
\hline GovEdLobao & 0 & 0 & 0 & 0 & 20 & 4 & 8 \\
\hline Entroncamento & 64 & 64 & 67 & 64 & 44 & 44 & 45 \\
\hline Imigrante & 12 & 7 & 5 & 6 & 5 & 4 & 4 \\
\hline Imbiral & 6 & 7 & 2 & 11 & 10 & 8 & 6 \\
\hline ItamaGuara & 0 & 0 & 0 & 0 & 10 & 10 & 4 \\
\hline JdAmerica & 1 & 0 & 0 & 0 & 0 & 1 & 0 \\
\hline JdMoradadoSol & 4 & 3 & 5 & 1 & 3 & 2 & 1 \\
\hline JDOriental & 0 & 2 & 0 & 1 & 2 & 1 & 5 \\
\hline JrLopes & 0 & 0 & 0 & 0 & 5 & 1 & 3 \\
\hline JdSaoFrancisco & 0 & 5 & 1 & 0 & 5 & 1 & 3 \\
\hline JDSaoLuis & 8 & 25 & 43 & 44 & 26 & 33 & 33 \\
\hline JdSumare & 0 & 1 & 1 & 1 & 1 & 1 & 4 \\
\hline Jlisboa & 0 & 0 & 0 & 0 & 3 & 1 & 6 \\
\hline
\end{tabular}


Table 2 - Continued from previous page

\begin{tabular}{|c|c|c|c|c|c|c|c|}
\hline \multirow{2}{*}{ Bairro } & \multicolumn{7}{|c|}{ Ano } \\
\hline & 2010 & 2011 & 2012 & 2013 & 2014 & 2015 & 2016 \\
\hline JdTropical & 2 & 4 & 5 & 7 & 3 & 10 & 12 \\
\hline Jussara & 82 & 76 & 72 & 94 & 54 & 56 & 67 \\
\hline LagoaVerde & 15 & 18 & 19 & 17 & 13 & 17 & 13 \\
\hline MaranhaoNovo & 30 & 19 & 21 & 29 & 35 & 26 & 32 \\
\hline Mercadinho & 38 & 61 & 43 & 54 & 49 & 41 & 33 \\
\hline MoradadoBosque & 0 & 0 & 0 & 1 & 0 & 0 & 0 \\
\hline Mutirao & 3 & 2 & 2 & 4 & 1 & 7 & 0 \\
\hline NovoHorizonte & 3 & 11 & 4 & 5 & 10 & 7 & 2 \\
\hline NovaImperatriz & 243 & 363 & 304 & 302 & 231 & 173 & 203 \\
\hline NovaVila & 0 & 0 & 1 & 0 & 0 & 0 & 0 \\
\hline Ouroverde & 6 & 14 & 17 & 9 & 7 & 7 & 7 \\
\hline PqAlvoradaUm & 48 & 69 & 20 & 11 & 8 & 8 & 7 \\
\hline PqAlvoradaDois & 12 & 12 & 40 & 26 & 20 & 20 & 16 \\
\hline PqAmazonas & 10 & 22 & 22 & 26 & 19 & 26 & 23 \\
\hline PqAnhanguera & 20 & 20 & 22 & 15 & 9 & 8 & 8 \\
\hline PqDasEstrelas & 4 & 6 & 7 & 6 & 7 & 10 & 10 \\
\hline PqDasMangueiras & 0 & 10 & 3 & 4 & 3 & 6 & 4 \\
\hline PqDasPalmeiras & 2 & 7 & 8 & 7 & 13 & 14 & 8 \\
\hline PqDoBuriti & 17 & 14 & 15 & 13 & 13 & 10 & 15 \\
\hline PqDosBosques & 0 & 0 & 1 & 0 & 0 & 1 & 2 \\
\hline PqIndependencia & 0 & 3 & 1 & 1 & 0 & 0 & 2 \\
\hline PqLagoinha & 3 & 2 & 0 & 2 & 1 & 2 & 1 \\
\hline PqPlanalto & 5 & 18 & 12 & 21 & 3 & 15 & 14 \\
\hline PqSantaLucia & 25 & 46 & 49 & 39 & 23 & 19 & 30 \\
\hline PqSenharol & 0 & 3 & 5 & 3 & 2 & 2 & 4 \\
\hline PqTocantins & 1 & 6 & 1 & 10 & 1 & 6 & 2 \\
\hline PauDaPreguica & 0 & 0 & 1 & 0 & 0 & 0 & 0 \\
\hline PortodaBalsa & 2 & 2 & 4 & 5 & 2 & 0 & 2 \\
\hline PovoadoCajueiro & 0 & 0 & 1 & 0 & 0 & 0 & 0 \\
\hline PovoadoCampolina & 0 & 0 & 0 & 0 & 0 & 0 & 0 \\
\hline PovoadoJiboia & 0 & 0 & 1 & 1 & 0 & 0 & 0 \\
\hline PovoadoMaozinha & 0 & 0 & 0 & 0 & 0 & 0 & 0 \\
\hline PraiadoCacau & 0 & 4 & 2 & 0 & 0 & 5 & 2 \\
\hline RecUniversitario & 0 & 0 & 0 & 0 & 5 & 3 & 7 \\
\hline SantaInes & 14 & 12 & 10 & 8 & 5 & 13 & 10 \\
\hline SantaRita & 115 & 167 & 182 & 139 & 106 & 115 & 119 \\
\hline SantoAmaro & 2 & 0 & 1 & 0 & 0 & 0 & 0 \\
\hline SaoJose & 23 & 37 & 52 & 34 & 24 & 27 & 23 \\
\hline SãoJdoEgito & 9 & 1 & 0 & 3 & 0 & 0 & 0 \\
\hline
\end{tabular}


Table 2 - Continued from previous page

\begin{tabular}{|c|c|c|c|c|c|c|c|}
\hline \multirow{2}{*}{ Bairro } & \multicolumn{7}{|c|}{ Ano } \\
\hline & 2010 & 2011 & 2012 & 2013 & 2014 & 2015 & 2016 \\
\hline SaoSalvador & 0 & 0 & 0 & 0 & 0 & 1 & 1 \\
\hline SenLaRocque & 0 & 0 & 0 & 0 & 1 & 2 & 0 \\
\hline SetorRodoviario & 31 & 43 & 44 & 33 & 21 & 21 & 20 \\
\hline SolNascente & 0 & 4 & 2 & 1 & 0 & 1 & 1 \\
\hline SuperQuadra602 & 0 & 1 & 0 & 0 & 0 & 0 & 0 \\
\hline TresPoderes & 35 & 27 & 24 & 34 & 33 & 20 & 24 \\
\hline VilaBrasil & 4 & 10 & 10 & 16 & 10 & 2 & 3 \\
\hline VilaCafeteira & 23 & 41 & 59 & 41 & 18 & 35 & 30 \\
\hline VilaChicodoRadio & 5 & 6 & 14 & 1 & 3 & 4 & 1 \\
\hline VilaConceicao & 5 & 5 & 8 & 4 & 0 & 1 & 10 \\
\hline VilaDavi2 & 5 & 2 & 7 & 6 & 10 & 7 & 2 \\
\hline VilaEsmeralda & 1 & 0 & 2 & 3 & 1 & 8 & 2 \\
\hline VilaFiquene & 16 & 8 & 7 & 11 & 6 & 11 & 7 \\
\hline VilaIndependencia & 4 & 5 & 6 & 2 & 6 & 3 & 1 \\
\hline VilaIpiranga & 9 & 16 & 19 & 20 & 9 & 13 & 10 \\
\hline VilaJK & 24 & 37 & 12 & 19 & 24 & 15 & 26 \\
\hline VilaJoaoCastelo & 11 & 12 & 11 & 17 & 8 & 12 & 11 \\
\hline VilaLeandra & 1 & 1 & 0 & 2 & 1 & 3 & 0 \\
\hline VilaLobao & 78 & 112 & 116 & 99 & 54 & 79 & 72 \\
\hline VilaMacedo & 4 & 6 & 3 & 7 & 9 & 3 & 4 \\
\hline VilaMachado & 1 & 1 & 0 & 1 & 0 & 2 & 2 \\
\hline VilaMadernina & 2 & 6 & 0 & 2 & 0 & 0 & 1 \\
\hline VilaMaria & 1 & 0 & 0 & 1 & 5 & 1 & 0 \\
\hline VilaMilitar & 0 & 0 & 0 & 0 & 0 & 0 & 0 \\
\hline VilaNegrao & 0 & 0 & 0 & 0 & 0 & 0 & 0 \\
\hline VilaNova & 74 & 91 & 79 & 64 & 54 & 50 & 52 \\
\hline VilaPalmares & 1 & 1 & 1 & 2 & 8 & 1 & 1 \\
\hline VilaParati & 0 & 1 & 0 & 4 & 2 & 1 & 3 \\
\hline VilaREdencao & 21 & 36 & 44 & 50 & 48 & 48 & 41 \\
\hline VilaSantaLuzia & 0 & 0 & 0 & 0 & 1 & 0 & 2 \\
\hline VilaVitoria & 12 & 12 & 8 & 17 & 10 & 13 & 14 \\
\hline VilaZenira & 4 & 2 & 1 & 1 & 0 & 1 & 1 \\
\hline Vilinha & 26 & 39 & 45 & 34 & 28 & 21 & 24 \\
\hline Total & 2500 & 3617 & 3413 & 2970 & 2536 & 2290 & 2385 \\
\hline
\end{tabular}

After carrying out the analysis and tabulation necessary to calculate the barycenter using the R-Studio software, it was possible to group the service points that represent the points with the highest occurrence of events, allowing the generation of points of demand in 05 main clusters, as shown in Tables 3, 4, 5, 6 and 7. 
[1] "cluster 1"

Table 3 - Cluster 01.

\begin{tabular}{|c|c|c|c|c|c|c|c|}
\hline Neighborhood / Year & 2010 & 2011 & 2012 & 2013 & 2014 & 2015 & 2016 \\
\hline 1 MileSetessentos & 0 & 1 & 5 & 11 & 8 & 8 & 10 \\
\hline 2 CincoIrmaos & 1 & 5 & 2 & 3 & 3 & 12 & 7 \\
\hline 3 AguaBoa & 0 & 0 & 1 & 1 & 5 & 0 & 0 \\
\hline 4 AltoBonito & 4 & 2 & 2 & 0 & 8 & 2 & 1 \\
\hline 5 AltodaBoaVista & 0 & 0 & 0 & 0 & 0 & 0 & 0 \\
\hline 6 AsaNorte & 4 & 3 & 1 & 1 & 5 & 0 & 0 \\
\hline 7 AyrtonSena & 7 & 6 & 10 & 6 & 1 & 2 & 2 \\
\hline 8 Bacaba & 5 & 1 & 1 & 1 & 0 & 0 & 0 \\
\hline 9 Uniao & 3 & 1 & 5 & 0 & 8 & 2 & 6 \\
\hline 10 PonteDomAfonso & 5 & 0 & 1 & 6 & 7 & 5 & 6 \\
\hline
\end{tabular}

Source: Elaborated by the Authors.

[1] "cluster 2"

Table 4 - Cluster 02.

\begin{tabular}{lccccccc}
\hline Neighborhood / Year & 2010 & 2011 & 2012 & 2013 & 2014 & 2015 & 2016 \\
\hline 1 PedroNSantana & 79 & 121 & 151 & 91 & 82 & 73 & 78 \\
2 BR010Rural & 61 & 165 & 109 & 59 & 39 & 18 & 6 \\
3 Entroncamento & 64 & 64 & 67 & 64 & 44 & 44 & 45 \\
4 Jussara & 82 & 76 & 72 & 94 & 54 & 56 & 67 \\
5 SantaRita & 115 & 167 & 182 & 139 & 106 & 115 & 119 \\
6 VilaLobao & 78 & 112 & 116 & 99 & 54 & 79 & 72 \\
7 VilaNova & 74 & 91 & 79 & 64 & 54 & 50 & 52 \\
\hline
\end{tabular}

Source: Elaborated by the Authors.

[1] "cluster 3"

Table 5 - Cluster 03.

\begin{tabular}{lccccccc}
\hline Neighborhood / Year & 2010 & 2011 & 2012 & 2013 & 2014 & 2015 & 2016 \\
\hline 1 Bacuri & 205 & 343 & 318 & 239 & 169 & 194 & 201 \\
2 BR010Urbano & 206 & 278 & 320 & 362 & 289 & 223 & 210 \\
3 NovaImperatriz & 243 & 363 & 304 & 302 & 231 & 173 & 203 \\
\hline
\end{tabular}

Source: Elaborated by the Authors. 
[1] "cluster 4"

Table 6 - Cluster 04.

\begin{tabular}{lccccccc}
\hline Neighborhood / Year & 2010 & 2011 & 2012 & 2013 & 2014 & 2015 & 2016 \\
\hline 1 BeiraRio & 24 & 56 & 54 & 36 & 19 & 18 & 14 \\
2 BocaDaMAta & 32 & 30 & 33 & 27 & 18 & 18 & 29 \\
3 BomSucesso & 47 & 75 & 55 & 28 & 52 & 27 & 23 \\
4 CocoGrande & 13 & 18 & 21 & 18 & 26 & 40 & 24 \\
5 Cjvitoria & 23 & 23 & 23 & 22 & 25 & 18 & 17 \\
6 EstradadoArroz & 0 & 0 & 10 & 16 & 25 & 29 & 44 \\
7 JDSaoLuis & 8 & 25 & 43 & 44 & 26 & 33 & 33 \\
8 MaranhaoNovo & 30 & 19 & 21 & 29 & 35 & 26 & 32 \\
9 Mercadinho & 38 & 61 & 43 & 54 & 49 & 41 & 33 \\
10 PqAlvoradaUm & 48 & 69 & 20 & 11 & 8 & 8 & 7 \\
11 PqAlvoradaDois & 12 & 12 & 40 & 26 & 20 & 20 & 16 \\
12 PqAmazonas & 10 & 22 & 22 & 26 & 19 & 26 & 23 \\
13 PqSantaLucia & 25 & 46 & 49 & 39 & 23 & 19 & 30 \\
14 SaoJose & 23 & 37 & 52 & 34 & 24 & 27 & 23 \\
15 SetorRodoviario & 31 & 43 & 44 & 33 & 21 & 21 & 20 \\
16 TresPoderes & 35 & 27 & 24 & 34 & 33 & 20 & 24 \\
17 VilaCafeteira & 23 & 41 & 59 & 41 & 18 & 35 & 30 \\
18 VilaJK & 24 & 37 & 12 & 19 & 24 & 15 & 26 \\
19 VilaREdencao & 21 & 36 & 44 & 50 & 48 & 48 & 41 \\
20 Vilinha & 26 & 39 & 45 & 34 & 28 & 21 & 24 \\
\hline
\end{tabular}

Source: Elaborated by the Authors.

[1] "cluster 5"

Table 7 - Cluster 05.

\begin{tabular}{lccccccc}
\hline Neighborhood / Year & 2010 & 2011 & 2012 & 2013 & 2014 & 2015 & 2016 \\
\hline 1 Centro & 509 & 775 & 650 & 493 & 510 & 414 & 475 \\
\hline
\end{tabular}

Source: Elaborated by the Authors.

With the tabulated information, still using the "R-Studio" software, it was possible to generate a visualization of the distribution of these clusters, in a grouped manner, where a large cloud of service points can be observed, through which 5 clusters were generated, represented by Figure 3 . The cloud generated in the graph represents the proximity between several of the service points, with a high rate of service by the ambulances, which confirms the need for an operational base so that a more agile and efficient service can be performed.

After grouping carried out, the software R-Studio was again used to define the best location, based on the five clusters presented, to which the result shown in Figure 4 could be obtained.

Figure 4 confirms the information previously generated that there is a large grouping of nearby locations with a higher demand for calls for assistance, which confirms the need to allocate an 


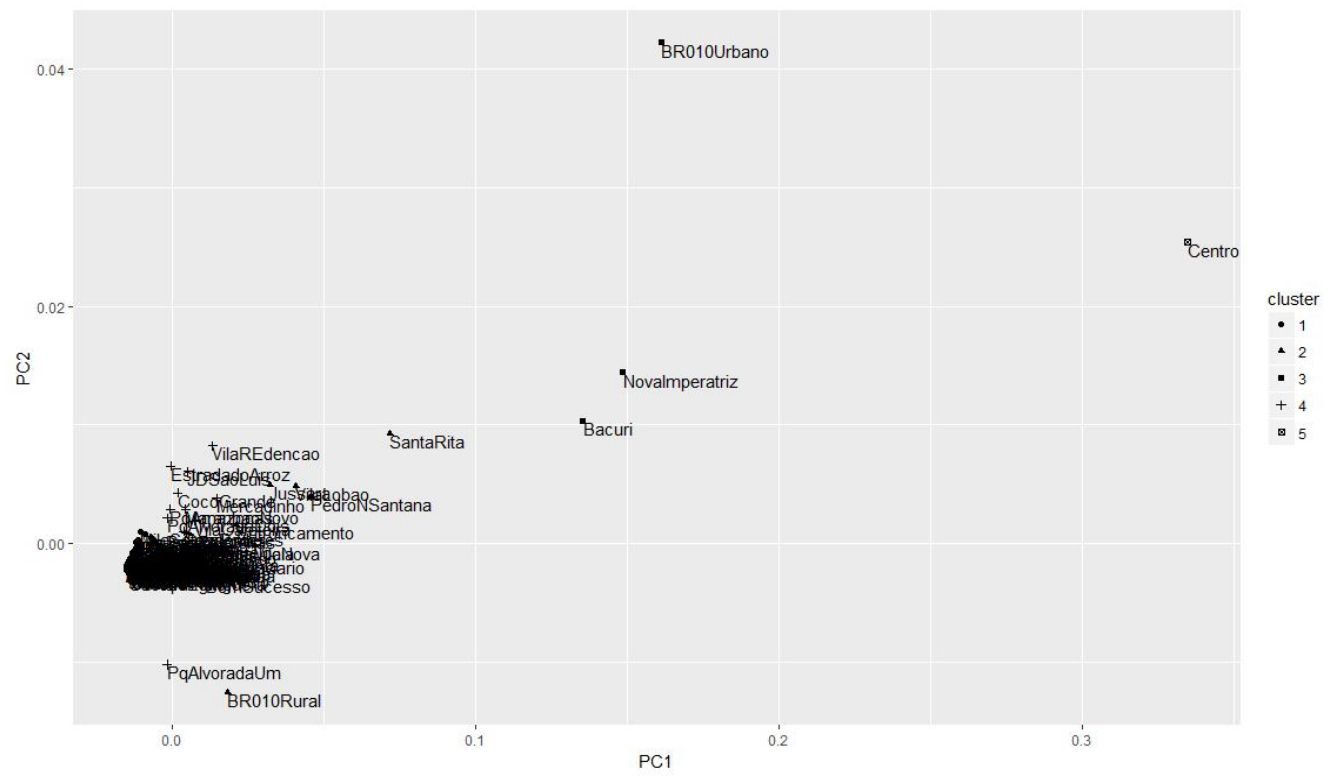

Figure 3 - Cluster clustering.

Source: elaborated by the authors.

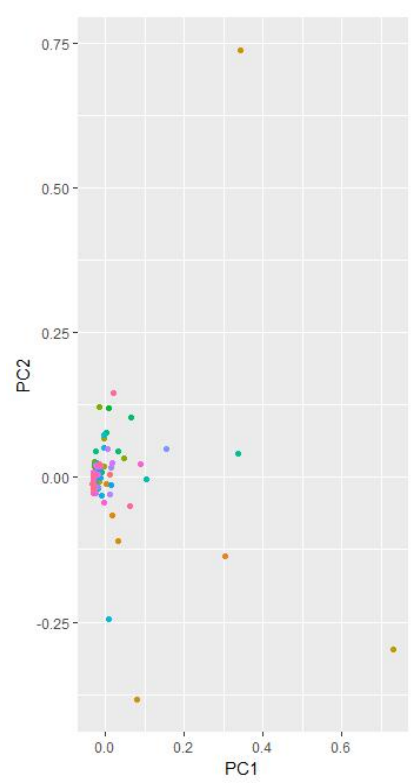

Ano

- AguaBoa Cincolrmaos - JDSaoLuis PovoadoCajueiro - RecUniversitario - Vilalndependencia

- AltoBonito o Cjerano

- RecUniverstoroadocampolna Santines

- Vilalpiranga

- JdTropical

- PovoadoCampolina - Santalnes

- VilaJk

- AsaNorte CjPlanalto - Jlisboa

- PovoadoMaozinha - SantoAmaro

- VilaJoaocastelo

- Ayrtonsena - Cjuitoria

- JrLopes

- PqAlvoradaDois - SãoJdoEgito

- VilaLeandra

- Bacaba CocoGrande - Jussara

- PqAlvoradaUm - SaoJose

- VilaLobao

- Bacuri

- CristoRei

- LagoaVerde

- PqAmazonas

- SaoSalvador

- VilaMacedo

- BarraGrande

- Curtume

- MaranhaoNovo

- PqAnhanguera SenLaRocque

- VilaMachado

- Davinopolis - Mercadinho

- PaDasEstrelas

- SetorRodoviario - VilaMadernina

- BeiraRio

- Entroncamento - MileSetessentos

- PqDasMangueiras - SolNascente

- Vilamaria

- BocaDaMAta - EstradadoArroz - MoradadoBosque - PaDasPalmeiras - SuperQuadra602 - VilaMilitar

- Bomjesus a govedtobar - Mutrao

- Bomsucesso - Habitar Brasil - Novalmperatriz PqDosBosques Uniao - VilaNova

- BR010Rural - Imbiral NovaVila PqIndependencia - VilaBrasil - VilaPalmares

- BR010Urbano - Imigrante - NovoHorizonte

- Cacauzinho - ItamaGuara

- PqLagoinha

- VilaCafeteira

- VilaParati

- Caema - JdAmerica PauDaPreguica

VilaChicodoRadio - VilaREdencao

- Camacari

- JdMoradadoSol - PedroNSantana

PqSantaLucia

- VilaConceica

- Centro - JDOriental

- VilaDavi2

- VilaSantaLuzia

- Centronovo

- JdSaoFrancisco - PortodaBalsa

- PqTocantins

- VilaEsmerald

- VilaVitoria

- Vilinha

Figure 4-Grouping of service points.

Source: elaborated by the authors. 
operational base to decrease the time of service and speed up the process of helping victims of accidents.

The tabulated data also allowed to assign significant levels of correlation for each of the clusters generated by the tabulation of the data presenting the following information:

Table 8 - Evaluation of the correlation of the generated Clusters.

\begin{tabular}{cccccc}
\hline Information & Cluster 1 & Cluster 2 & Cluster 3 & Cluster 4 & Cluster 5 \\
\hline$[1]$ & 0.8758162 & 0.8715476 & 0.9400000 & 0.8814893 & 0.5600000 \\
\hline \multicolumn{5}{c}{ Source: elaborated by the authors. }
\end{tabular}

In view of the above, it was possible to observe that, among the five clusters generated, cluster number 3, composed of the neighborhoods Bacuri, Br 010 Urbano and Nova Imperatriz, appears indicated as the best location for the operational base, with $94 \%$ confidence, in estmated conclusion, it is possible to state that $94 \%$ of the time, the best option for the location of the operational base would be one of these three neighborhoods.

Once the best locations for the operational bases were calculated through the calculation of the barycenter, an attempt was made to compare the suggested locations with the current locations of the bases in operation. In this sense, it was noticed that SAMU currently has two operational bases located in the neighborhoods that make up cluster 3, one of them in the Bacuri neighborhood and the other in the Bernardo Sayao Avenue in Nova Imperatriz neighborhood, an avenue of great circulation, easy flow traffic and with easy access to several neighborhoods in the city, which confirms that the current location of the operational bases are adequate to the service flow observed through the calculation of the center, based on the history of the occurrences of the last seven years.

\section{CONCLUSION}

The main objective of this article was to use Operational Research to perform the calculation for locating an operational base, using the barycenter calculation method, based on the service history. This objective was achieved by performing a quantitative analysis, with the help of the R-Studio software, which allowed grouping the data into clusters capable of portraying the geographical distribution of the service points.

The results obtained through the barycenter calculations generated an agglomeration of five clusters, attributing the degree of attractiveness to each one of them and suggesting the most suitable, which points out the most attractive cluster for $94 \%$ of the attendance occurrences, validating the proposed method. Thus, the objective of the article was achieved, since the method of calculating the barycenter proved to be an efficient tool for determining the location of the operational base of ambulances.

The use of the proposed method made it possible to identify the best possible choice (Fuller, 1997) among the existing options to improve the level of coverage (Arakaki and Lorena, 2006) of care, proving to be as efficient as the heuristic methods (Church \& Revelle, 1974; Hamon et al., 1979; Chiyoshi \& Galvão, 2000; Gu, Wang \& Geng, 2009), as for the deterministic methods (Yin 
\& Mu, 2012; Haghani, 1996; Alsalloum \& Rand, 2006), the stochastic methods or probabilistic (Figueiredo et al., 2005; Takeda et al., 2004; Iannoni et al., 2009) or as for the dynamic methods (Figueiredo et al., 2005; Takeda et al, 2004; Iannoni et al. 2009).

In this way, it is concluded that the Operational Research, through the barycenter method can be used as a tool to determine an operational base, based on the analysis of the service history and that the R-Studio software, as a technological resource, allows to carry out the analyzes accurately and reliably.

As an academic contribution, this article presents the possibility of using historical data from previous visits to determine the best location for an operational base. However, as a limitation, it presents the fact that it was carried out with data from only one municipality, however, due to the amount of data analyzed, it believes that this does not make the method unfeasible.

As a suggestion for future research, it is suggested to replicate the method in other locations, with the same purpose and also using other examples of logistics network that need to analyze the best option for determining an operational base.

\section{References}

[1] ANDRADE LAC. 2012. Heurística baseada em colônia artificial de abelhas para o problema de localização de bases, alocação e realocação de ambulâncias. 2012. Dissertação (Mestrado em Engenharia de Sistemas Logísticos). Universidade de São Paulo, Escola Politécnica, São Paulo. 250 p.

[2] Albuquerque ll, Almeida AT \& Cavalcante CAV. 2009. Aplicabilidade da programação matemática multiobjetivo no planejamento da expansão de longo prazo da geração no brasil. Pesquisa operacional 29(1): 153-177.

[3] Alsalloum OI \& RAND GK. 2006. Extensions to emergency vehicle location models. Computers \& Operations Research, 33: 2725-2743.

[4] Aquilano N, Chase R \& Davis M. 2000. Fundamentos da administração da produção. Porto Alegre: Bookman.

[5] AQUiNo DI. 2007. Caracterização do serviço de atendimento móvel de urgência (samu 192) do município de Florianópolis/SC. Dissertação de mestrado. Universidade do Vale do Itajaí, Itajaí.

[6] ARAKAKI RGI \& LORENA LAN. 2006. Uma heurística de localização-alocação (Hla) para problemas de localização de facilidades. Prod. [online], 16(2): pp.319-328. http: //dx.doi.org/10.1590/S0103-65132006000200011.

[7] BALL MO \& LIN FL. 1993. A reliability model applied to emergency service vehicle location. Operations Research, 41: 18-36.

[8] Ballou RH. 2006. Gerenciamento da Cadeia de Suprimentos/Logística Empresarial. São Paulo: Bookman. 
[9] BALlou RH. 2005. Gerenciamento da cadeia de suprimentos: logística empresarial. Porto Alegre: Bookman.

[10] Barrachina J, Garrido P, Fogue M, Martinez FJ, Cano JC, Calafate CT \& MANZONI P. 2014. Reducing emergency services arrival time by using vehicular communications and Evolution Strategies. Expert Systems with Applications, 41: 12061217.

[11] Bertelli A, Bueno MR \& Sousa RMC. 1999. Estudo preliminar das relações entre duração da parada cardiorrespiratória e suas consequências nas vítimas de trauma. Revista da Escola de Enfermagem da USP, 33(2), 130-141. http://dx.doi.org/10.1590/ S0080-62341999000200004. Acessado em 08.09.2017.

[12] Brasil. 2017. Palácio do Planalto. Governo Renova Frota Do SAMU com 340 Ambulâncias. Disponível em: http://www2.planalto.gov.br/acompanhe-planalto/ noticias/2017/01/governo-renova-frotas-do-samu-com-340-ambulancias Acessado em 05.09.2017.

[13] Chiyoshi FY \& GALVÃo RD. 2000. A statistical analysis of simulated annealing applied to the pmedian problem. Operations Research, 96: 61-70.

[14] Church R \& Revelle C. 1974. The maximal covering location problem. Papers of the Regional Science Association, 32:101118.

[15] Clareto SM, Silva AA \& Clemente JC. 2013. De triângulo a bola: uma matemática menor e a sala de aula. XI Encontro Nacional de Educação Matemática Curitiba Paraná, 20 a 23 de julho de 2013.

[16] CRYochi F, GALVÃo RD \& Morabito R Modelo hipercubo: análise e resultados para o caso de servidores não-homogêneos. Pesquisa Operacional, 21(2): p.199-218, julho a dezembro de 2001 .

[17] DASKIN MS \& STERN EH. 1981. A hierarchical objective set covering model for emergency medical service vehicle deployment. Transportation Science, 15: 137-152.

[18] DASKIN MS. 1983. A maximum expected location model: formulation, properties and heuristic solution. Transportation Science, 7: 48-70.

[19] DATASUS. 2017. Departamento de Informática do SUS. Histórico SAMU. Disponível em http://datasus.saude.gov.br/projetos/52-samu. Acessado em 05.09.2017.

[20] DENATRAN - Departamento Nacional de Trânsito, Ministério das Cidades. Disponível em: http://cidades.ibge.gov.br/painel/frota.php?codmun=211130\&lang=_ES. Acessado em 02.09.2017.

[21] Farahani RZ, Asgari N, Heidari N, Hosseininia M \& Goh M. 2012. Covering problems in facility location: a review. Computers \& Industrial Engineering, 62: 368-407. 
[22] FERRARI T \& NASSi CD. 2015. Análise comparativa dos métodos de alocação para localização de postos de despacho de ambulâncias de resgate. Anais do XIII Rio de Transportes. Rio de Janeiro, Brasil, 19 e 20 de Agosto 2015. p. 3.

[23] Figueiredo APS \& LorenA LAN. 2005. Localização de Ambulâncias: Uma aplicação para a cidade de São José dos Campos SP. Anais XII Simpósio Brasileiro de Sensoriamento Remoto, Goiânia, Brasil, 16-21 abril 2005, INPE, p. 1965-1972.

[24] Fitzsimmons J \& Fitzsimmons M. 2004. Administração de serviços. Porto Alegre: Porto Alegre: Bookman.

[25] Fogue M, Garrido P, Martinez FJ, Cano J-C., Calafate CT \& Manzoni P. 2013. A novel approach for traffic accidents sanitary resource allocation based on multiobjective genetic algorithms. Expert Systems with Applications, 40(1): 323336.

[26] Fuller DE. 1997. Optimizing Airborne Area Surveillance Asset Placement, Tese (Mestrado em Análise Operacional). Ohio: Air Force Institute of Technology.

[27] Gabriel CPC, Gabriel Filho lRA, Bife SF, Andrade SL \& Oliveira FRZ. 2006. Determinação geométrica e econômica da posição de armazéns de estocagem entre cidades do oeste paulista. etic - encontro de iniciação científica, 2(2).

[28] Galvão R, Nobre F \& Vasconcellos M. 1999. Modelos matemáticos de localização aplicados à organização espacial de unidades de saúde. Revista de Saúde Pública, 33(4): p.422-34.

[29] Gendreau M, Laporte G \& Semet F. 2001. A dynamic model and parallel Tabu search heuristic for real-time ambulance relocation. Parallel Computing, 27: 16411653.

[30] Gu W, Wang X \& Geng L. 2009. GIS-FL Solution: a spatial analysis platform for static and transportation facility locational location problem. Anais do International Symposiumon Methodologies for Intelligent Systems, Praga, v. 28.

[31] Haghani A. 1996. Capacitated maximum covering location models: formulations and solution procedures. Journal of Advanced Transportation, 30(3): 101-136.

[32] Hamon B, EATON D \& CHURCh R. 1979. Development of a multi-purpose ambulance system.

[33] Hogan K \& Revelle CS. 1986. Concepts and applications of backup coverage. Management Science, 34: 1434-1444.

[34] IANNONi AP \& Morabito R. 2006. Modelo de fila hipercubo com múltiplo despacho e backup parcial para análise de sistemas de atendimento médico emergenciais em rodovias. Pesquisa Operacional, 26(3): 493-519. 
[35] IAnnoni AP, Morabito R \& SAydam C. 2009. An optimization approach for ambulance location and the districting of the response segments on highways. Transportation Research Part E: Logistics and Transportation Review, 43(6): 755771.

[36] IBGE - Instituto Brasileiro de Geografia e Estatística. 2017. Disponível em http://www.cidades.ibge.gov.br/xtras/perfil.php?lang=\&codmum=2105302. Acessado em 02.09.2017.

[37] Jatain A \& RANJAn A. 2017. A review study on big data analysis using R studio. International Journal of Computer Science and Mobile Computing, 6(6): 8-13.

[38] LARSON RC \& Odoni AR. 1981. Urban Operations Research. Prentice Hall, New Jersey.

[39] LEFEBVRE L \& SEILER L. 2004. Barycentric centroid sampling method and apparatus. U.S. Patent n. 6,768,491, 27 jul.

[40] LORENA L. 2003. Análise espacial de redes com aplicações em sistemas de informações geográficas. Prod. [online], 3(2): p.1-24, 2003. http://dx.doi.org/10.14488/1676-1901. v3i2.623.

[41] Marianov V \& Revelle CS. 1996. The queueing maximal availability location problem: a model for sitting of emergency vehicles. European Journal of Operational Research, 93: 110-120.

[42] Matte Júnior AA, Gehres FF, Gehres T \& Sellitto M. 2017. Realocação de um fabricante de autopeças utilizando o método do baricentro e análise qualitativa. Iberoamerican Journal of Industrial Engineering, 9(17): 62-79.

[43] Mazuelas S ET AL. 2010. Topology assessment provided by weighted barycentric parameters in harsh environment wireless location systems. IEEE Transactions on Signal Processing, 58(7): 3842-3857.

[44] NARUo M. 2003. O estudo do consórcio entre municípios de pequeno porte para disposição final de resíduos sólidos urbanos utilizando sistema de informações geográficas. Dissertação de Mestrado em Engenharia de Transportes. USP, São Carlos.

[45] Pollit D, Beck C \& Hungler B. 2004. Fundamentos de pesquisa: métodos, avaliação e utilização. Porto Alegre: Artmed.

[46] Rajagopalan HK, Saydam C \& Xiao J. 2008. A multi-period set covering location model for dynamics redeployment of ambulances. Computers \& Operations Research, 35(3): 814-826.

[47] Revelle CS \& Hogan K. 1989. The maximum availability location problem. Transportation Science, 23: 192-200. 
[48] Schmid V \& Doerner KF. 2010. Ambulance location and relocation problems with time-dependent travel times. European Journal of Operational Research, 207: 1293-1303.

[49] Schmid V. 2012. Solving the dynamic ambulance relocation and dispatching problem using approximate dynamic programming. European Journal of Operational Research, 219: 611-621.

[50] Sellitto M, Borchardt M, Pereira G \& Silva B. 2009. Avaliação de duas alternativas para distribuição de autopeças considerando centros de distribuição CD's. INGEPRO, 01(01): 01-17.

[51] Silva EL \& Menezes EM. 2001. Metodologia da pesquisa e elaboração da dissertação. Florianópolis: Universidade Federal de Santa Catarina.

[52] Sousa VA, BAPtista EC \& COSTA GRM. 2008. A resolução do problema de despacho ótimo de reativos pelo método da função lagrangiana-barreira relaxada. Pesquisa Operacional, 28(2): 303-320.

[53] TAKeda RA, Widmer JA \& Morabito R. 2004. Aplicação do modelo hipercubo de filas para avaliar a descentralização de ambulâncias em um sistema urbano de atendimento médico de urgência. Pesquisa Operacional, 24(1): 39-71.

[54] TeITZ MB \& BART P. 1968. Heuristic methods for estimating the generalized vertex median of a weighted graph. Operations Research, 16: 955-961.

[55] YIN P \& MU L. 2012. Modular capacitated maximal covering location problem for the optimal siting of emergency vehicles. Applied Geography, 34: 247-254.

\section{How to cite}

Sousa JC, Alves MB \& Belém JF. 2020. The Calculation of the Barycenter as a Criterion for Determining the Location of the Ambulance Operational Base. Pesquisa Operacional, 40: e218216. doi: 10.1590/0101-7438.2020.040.00218216. 